\title{
TINJAUAN YURIDIS TENTANG BENTUK-BENTUK PERLINDUNGAN HUKUM BAGI TENAGA KERJA YANG BEKERJA DI LAUT
}

\author{
Marsidah \\ Fakultas Hukum Univertsitas Palembang \\ e-mail: marsidahelan@gmail.com
}

\begin{abstract}
The risk of danger at sea is very large, shipping companies must guarantee the protection of workers on ships related to the risk of marine hazards without exception. The issue published in this discussion is a discussion of the legal form for workers who work at sea based on Law No. 13 of 2003 and number 7 in 2000. The type of research used in this research is normative juridical by assessing fuel-Section Number 13 of 2003 concerning employment and Government Regulation Number 7 of 2000 concerning seafarers and the responsibility of seafarers. Regarding the legal form for workers who work with legal protection for work time, occupational safety and health, and wages. In addition, in accordance with the applicable law in the Jamsostek Permit the right to wages, housing and house rights, the right to leave, the right to the time of illness or accident.
\end{abstract}

Keywords: Legal Protection; Labor

\section{ABSTRAK}

Risiko bahaya dilaut sangat besar maka perusahaan pelayaran harus memberikan jaminan perlindungan hukum tenaga kerja di kapal laut yang berkaitan dengan risiko bahaya dilaut tanpa terkecuali. Permasalahan yang diteliti dalam penulisan ini adalah bagaimanakah bentu-bentuk perlindungan hukum bagi tenaga kerja yang bekerja di laut berdasarkan uu no 13 tahun 2003 dan uu nomor 7 tahun 2000. Jenis penelitian yang digunakan dalam penelitian adalah yuridis normatif dengan mengkaji bahan-bahan kepustakaan yaitu Undang-Undang Nomor 13 Tahun 2003 ttg ketenagakerjaan dan Peraturan Pemerintah Nomor 7 Tahun 2000 tentang kepelautan dan gaji pelaut. Adapun bentuk perlindungan hukum bagi tenaga kerja yang bekerja dilaut meliputi perlindungan hukum yang diatwaktu kerja, keselamatan dan kesehatan kerja, dan pengupahan. Selain itu bentuk perlindungan hukum dalam peraturan jamsostek meliputi hak atas upah, hak tempat tinggal dan rumah, hak untuk cuti, hak waktu sakit atau kecelakaan.

\section{Kata Kunci : Perlindungan Hukum; Tenaga Kerja}

\section{PENDAHULUAN}

\section{A. Latar Belakang}

Dewasa ini masalah

ketenagakerjaan di bidang jasa transportasi semakin ramai dibicarakan di Indonesia, apalagi akhir-akhir ini banyak terjadi musibah yang bertubitubi menimpa jasa transportasi di Indonesia baik yang bergerak di darat, laut maupun udara.

Menyangkut masalah musibah pasti ada pihak yang dirugikan baik dari pihak pengguna jasa maupun pemberi jasa. Oleh sebab itu, perlindungan hukum sangat berperan penting untuk melindungi khususnya untuk tenaga kerja atau pekerja. Mengingat pentingnya peranan tenaga kerja atau pekerja dalam suatu perusahaan tidak akan berjalan tanpa adanya campur tangan tenaga kerja atau pekerja. Setiap pekerjaan baik di darat, laut, udara pasti ada resikonya. Dalam hal ini jenis pekerjaan yang dilakukan oleh tenaga kerja atau pekerja di kapal mempunyai resiko bahaya yang besar di dalam melaksanakan tugasnya pada saat berlayar.

Dalam hal resiko bahaya di laut yang sewaktu-waktu dapat menimpa tenaga kerja di kapal maka perusahaan pelayaran harus memperhatikan atau memberikan perlindungan secara jelas tanpa mengurangi hak tenaga kerja atau pekerja sedikit pun demi memperoleh keuntungan yang sebanyak-banyaknya. Menurut Pasal 2 ayat (2) Peraturan Pemerintah Nomor 1 Tahun 1998 
tentang Pemeriksaan Kecelakaan Kapal, ${ }^{1}$ disebutkan ada lima macam kecelakaan kapal yang sering terjadi yaitu :

1. Kapal tenggelam;

2. Kapal terbakar;

3. Kecelakaan kapal yang menyebabkan terancamnya jiwa manusia dan kerugian harta benda;

4. Kapal tubrukan;

5. Kapal kandas, dan sebagainya.

Mengingat resiko bahaya di laut sangat besar maka perusahaan pelayaran harus memberikan atau menjamin perlindungan hukum tenaga kerja di kapal yang berkaitan dengan resiko bahaya di laut tanpa terkecuali. Selain itu, seorang yang bekerja di kapal pasti jauh atau meninggalkan keluarga mereka untuk waktu yang lama. Maka perusahaan harus dapat memberikan keseimbangan antara hak dan kewajiban tenaga kerja baik kepada nahkoda maupun anak buah kapal. Misalnya : memberikan tunjangan kepada keluarga tenaga kerja atau pekerja, memberikan tunjangan hari tua, dan sebagainya.

Perlindungan hukum terhadap tenaga kerja atau pekerja berarti membahas hak dan kewajiban tenaga kerja atau pekerja tanpa terkecuali. Artinya hak-hak tenaga kerja atau pekerja setelah tenaga kerja melaksanakan kewajibannya. Hak dan kewajiban pekerja dituangkan dalam perjanjian kerja yang dibuat antara perusahaan dengan tenaga kerja tanpa adanya paksaan. Dimana perjanjian kerja merupakan awal dimulai hubungan kerja. Hak tenaga kerja di kapal menurut Pasal 18 ayat (3) Peraturan Pemerintah Nomor 7 Tahun 2000 Tentang Kepelautan, meliputi : Hak atas upah, hak atas tempat tinggal

\footnotetext{
1 Peraturan Pemerintah Nomor 1 Tahun 1998 Tentang Pemeriksaan Kecelakaan Kapal
}

dan makan, hak cuti, hak waktu sakit atau kecelakaan. Selain tersebut hak pekerja juga meliputi penyelesaian perselisihan bila terjadi hubungan kerja antara pekerja dan pengusaha.

Perjanjian kerja menjadi sarana dalam mewujudkan perlindungan hukum bagi tenaga kerja atau pekerja. Perjanjian kerja untuk tenaga kerja yang bekerja di darat diatur dalam Undang-Undang Nomor 13 Tahun 2003 tentang Ketenagakerjaan. Sedangkan perjanjian kerja untuk tenaga kerja/pekerja di kapal terdapat dalam Kitab Undang-undang Hukum Dagang (KUHD). Perjanjian kerja yang dilakukan tenaga kerja di kapal dengan perusahaan pelayaran disebut perjanjian kerja laut.

Perjanjian kerja laut adalah perjanjian kerja perorangan yang dibuat antara seorang pengusaha kapal di satu pihak dan seorang di pihak lain, dengan mana pihak tersebut terakhir menyanggupi untuk bertindak di bawah pengusaha itu melakukan pekerjaan dengan mendapat upah, sebagai nahkoda atau anak buah kapal (Pasal 395 Kitab Undang-undang Hukum Dagang). Sedangkan, menruut Pasal 1 Peraturan Pemerintah Nomor 7 Tahun 2000 tentang Kepelautan hanya memberikan pengertian secara eksplisit dan singkat mengenai perjanjian kerja laut. Perjanjian kerja laut adalah perjanjian yang ditandatangani oleh pelaut Indonesia dengan perusahaan pelayaran.

Perjanjian kerja laut untuk tenaga kerja di kapal dikelompokkan menjadi 2 (dua) yaitu perjanjian kerja laut untuk nahkoda, perjanjian kerja laut untuk anak buah kapal. ${ }^{2}$

Mengingat

persoalan

ketenagakerjaan bukan semata-mata

\footnotetext{
2 Djoko Triyanto, Bekerja di Kapal, Cetakan Pertama, Minar Maju, Bandung, Tahun 2006, hal. 46
} 
melindungi pihak yang lemah tetapi setidak-tidaknya dapat memberikan keseimbangan antara hak dan kewajiban tenaga kerja di kapal. Jika dilihat dari salah satu tujuan UndangUndang Nomor 13 Tahun 2003 tentang Ketenagakerjaan, diantaranya adalah agar pekerja mendapat jaminan kesejahteraan yang meliputi jaminan kesehatan, dan jaminan keselamatan kerja, waktu kerja serta mendapatkan upah sesuai dengan ketentuan yang tercantum dalam perjanjian kerja. Maka dalam lingkup tenaga kerja laut juga harus diberikan hak-hak pekerjanya dan bentuk-bentuk perlindungan tenaga kerjanya sesuai dengan sifat pekerjaan mereka yang tetap harus diperhatikan sehingga mereka dapat terlindungi oleh hukum sehingga seorang tenaga kerja tidak diperlakukan semena-mena atau dieksploitasi oleh pengusaha yang hanya mencari keuntungan pribadi saja tanpa memperhatikan kesejahteraan dan perlindungan hukum bagi tenaga kerjanya. Selain itu, untuk mengetahui apakah perusahaan memasukkan semua tenaga kerjanya ke dalam organisasi serikat pekerja, sebab pada dasarnya kebanyakan masalah hukum yang terjadi dalam lingkungan laut jarang terekspos. Selain itu, adanya dorongan sangat minimnya atau kurangnya pengetahuan masyarakat akan pandangan bahwa bekerja di laut itu enak dan tidak ada resiko yang besar. Keadaan tersebut dapat ditinjau dari bentuk pelaksanaan perlindungan hukumnya, baik dari segi perjanjian kerja, upah pekerja maupun tunjangan lainnya.

Berdasarkan uraian di atas, maka penulis berkeinginan mengadakan penelitian dengan judul Tinjauan Yuridis tentang Perlindungan Hukum Bagi atenaga Kerja di Laut.

permasalahan ; Bagaimanakah bentuk-bentuk perlindungan hukum bagi tenaga kerja yang bekerja di

\section{B. Perumusan Masalahan}

Adapun permasalahan dalam penelitian ini dapat dirumuskan sebagai berikut ; Bagaimanakah bentuk-bentuk perlindungan hukum bagi tenaga kerja di Laut berdasarkan Undang-undang Tomor 13 Tahun 2003 dan peraturan pemerintah nomor 7 tahun 2000 .

\section{C.Tujuan dan manfaat penelitian}

\section{Tujuan Penelitian}

Tujuan penelitian ini secara umum untuk mengetahui dan memahami bentuk perlindungan hukum bagi tenaga kerja yang bekerja dilaut.

\section{Manfaat Penelitian}

Adapun manfaat dalam penelitian ini adalah untuk pengembangan ilmu khususnya Hukum Dagang dan Hukum Ketenagakerjaan mengenai perlunya bentuk perlindungan hukum bagi tenaga kerja yang bekerja dilaut dan diharapkan dapat menjadi sumbangan pemikiran untuk dijadikan arah penelitian yang lebih lanjut pada masa yang akan datang.

\section{Metode Penelitian}

\section{Jenis Penelitian}

Jenis penelitian yang penulis gunakan dalam penelitian ini adalah jenis penelitian hukum normatif adalah penelitian dengan mengkaji bahan pustaka yang berbentuk undang-undang, peraturan-peraturan yang berkaitan dengan bentukbentuk perlindungan hukum terhadap pekerja yang bekerja di kapal laut. Menurut Undang-Undang Ketenagakerjaan dan Peraturan Pemerintah Nomor 7 Tahun 2000 tentang Kepelautan.

\section{Tipe Penelitian}

Tipe penelitian ini termasuk deskriptif yaitu penelitian yang bertujuan menggambarkan secara jelas dan terperinci tentang perlindungan hukum terhadap pekerja yang bekerja di kapal laut. Menurut Undang-Undang Ketenagakerjaan dan Peraturan Pemerintah Nomor 7 Tahun 2000. 


\section{Data dan Sumber Data}

Dalam penelitian ini data yang digunakan adalah data sekunder. Data sekunder yaitu data yang diperoleh dari peraturan perundangundangan dan buku-buku bacaan yang semuanya disebut pustaka. Data sekunder dalam penelitian ini terdiri dari :

a. Bahan hukum primer meliputi KUHD, Undang-Undang

Ketenagakerjaan, Peraturan

Pemerintah Nomor 7 Tahun 2000,

Peraturan Pemerintah Nomor 70

Tahun 2013.

b. Bahan hukum sekunder, meliputi buku-buku ilmu pengetahuan hukum, buku tentang ketenagakerjaan.

c. Bahan hukum tersier, yaitu Kamus Besar Bahasa Indonesia.

Metode yang digunakan dalam menganalisis dan mengolah data yang terkumpul dalam penelitian ini dilakukan secara kualitatif artinya yaitu dengan cara menyajikan dan menguraikan data dalam bentuk kalimat secara rinci dan sistematis, kemudian dilakukan interpretasi data, yaitu menguraikan data yang telah disusun tersebut sehingga diperoleh gambaran yang jelas mengenai permasalahan yang dibahas. Akhirnya pembahasan ini akan menuju pada suatu kesimpula terhadap bahasan yang akan diteliti.

\section{PEMBAHASAN}

\section{Pengertian Perlindungan Hukum}

Secara umum dapat dijelaskan bahwa pengertian perlindungan hukum adalah tindakan melindungi atau memberikan pertolongan dalam bidang hukum.

Menurut Kamus Besar Bahasa Indonesia (KBBI), yang dimaksud dengan hukum adalah peraturan yang dibuat oleh dat yang berlaku bagi semua orang dalam masyarakat (negara). Sedangkan, hukum pada dasarnya merupakan perlengkapan masyarakat untuk menjamin agar kebutuhan-kebutuhan dalam masyarakat dapat dipenuhi secara teratur agar tujuan-tujuan kebijaksanaan publik dapat terwujud di dalam masyarakat. Berbicara perlindungan hukum berarti membahas tentang hak dan kewajiban tenaga kerja. Perlindungan hukum terhadap tenaga kerja di kapal merupakan salah satu bagian yang sangat penting dalam pelaksanaan hak bekerja dalam perusahaan, apalagi mengingat resiko bahayanya, maka pekerjaan yang dilakukan oleh tenaga kerja di kapal haruslah sesuai dengan harkat dan martabat manusia itu sendiri.

Untuk menjamin hak-hak tenaga kerja di kapal tersebut, maka perlu dilakukan upaya pelaksanaan perlindungan hukum terhadap tenaga kerja di kapal tanpa terkecuali. Perlindungan hukum terhadap tenaga kerja dituangkan dalam Pasal 28D ayat (2) UUD 1945, yang berbunyi :

"Setiap orang berhak untuk bekerja serta mendapatkan imbalan dan perlakuan yang adil dan layak dalam hubungan kerja".

Tujuan perlindungan hukum sebagaimana tercantum dalam Pasal 4 Undang-Undang Nomor 13 Tahun 2003 tentang Ketenagakerjaan adalah memberikan perlindungan kepada tenaga kerja dalam mewujudkan kesejahteraan dan meningkatkan kesejahteraan tenaga kerja dan keluarganya.

Mengingat pentingnya peran tenaga kerja atau pekerja di kapal dalam sebuah perusahaan, maka tujuan perlindungan hukum terhadap tenaga kerja di kapal harus dilaksanakan sebagaimana mestinya. Tanpa harus membedakan satu dengan yang lain karena pada 
dasarnya setiap tenaga kerja berhak memperoleh perlindungan. Selain itu, dengan mengingat tenaga kerja di kapal memiliki resiko yang sangat besar dan sifat pekerjaannya menuntut untuk jauh dari keluarga mereka. Dengan begitu jika adanya keseimbangan antara hak dan kewajiban maka hubungan kerja dapat berjalan dengan lancar.

$$
\text { Pada dasarnya dalam }
$$

hubungan antara tenaga kerja dan pengusaha, secara yuridis pekerja dipandang sebagai orang yang bebas karena prinsip negara kita tidak seorangpun boleh diperbudak. Secara sosiologis, pekerja itu tidak bebas sebagai orang yang terpaksa untuk menerima hubungan kerja dengan pengusaha meskipun memberatkan bagi pekerja itu sendiri, lebih-lebih saat sekarang ini dengan banyaknya jumlah tenaga kerja yang tidak sebanding dengan lapangan yang tersedia. Akibatnya tenaga kerja sering kali diperas oleh pengusaha dengan upah yang relatif kecil dan tidak ada jaminan yang diberikan. Selain itu, tenaga kerja di kapal memiliki resiko yang sangat besar dan sifat pekerjaannya menuntut untuk jauh dari keluarga mereka. Mengingat hal tersebut perusahaan harus memberikan kepastian hukum kepada tenaga kerja atau pekerja di kapal.

Dengan adanya kejelasan tujuan perlindungan hukum terhadap tenaga kerja di kapal dapat memberikan kepastian hukum yang jelas dalam pelaksanaannya sehingga tenaga kerja tidak dirugikan.

\section{Bentuk Perlindungan Hukum Tenaga Kerja Di Kapal}

Bentuk jaminan perlindungan hukum terhadap tenaga kerja diatur dalam Undang-Undang Nomor 13 Tahun 2003 tentang Ketenagakerjaan antara lain :

\section{1) Waktu Kerja}

Waktu kerja diatur dalam Pasal 77 Undang-Undang Nomor 13 Tahun 2003 tentang Ketenagakerjaan. Oleh sebab itu, setiap pengusaha wajib melaksanakan ketentuan waktu kerja, sebagaimana dalam Pasal 77 ayat (2) Undang-Undang Nomor 13 Tahun 2003 tentang Ketenagakerjaan.

Selain itu, pengusaha wajib memberikann waktu cuti dan istirahat kepada pekerja. Hal tersebut diatur dalam Pasal 79 ayat (2) yaitu :

(1) Istirahat antara jam kerja, sekurangkurangnya setengah jam setelah bekerja selama 4 jam terusmenerus dan waktu istirahat tidak termasuk jam kerja.

(2) Istirahat mingguan 1 (satu) hari untuk 6 (enam) hari kerja dalam 1 (satu) minggu atau 2 (dua) hari untuk 5 (lima) hari kerja dalam 1 (satu) minggu.

(3) Cuti tahunan, sekurangkurangnya 12 (dua belas) hari kerja setelah pekerja yang bersangkutan bekerja selama 12 (dua belas) bulan secara terusmenerus.

(4) Istirahat panjang sekurang-kurangnya 2 (dua) bulan, dan dilaksanakan pada tahun ke tujuh dari ke delapan masing-masing 1 (satu) bulan bagi pekerja yang telah bekerja selama 6 (enam) tahun secara terus-menerus pada perusahaan yang sama dengan ketentuan 
pekerja tersebut tidak berhak lagi atas istirahat tahunannya dalam 2 (dua) tahun berjalan dan selanjutnya berlaku untuk setiap kelipatan masa kerja 6 (enam) tahun.

\section{2) Keselamatan dan Kesehatan Kerja}

Pengertian keselamatan kerja adalah keselamatan yang bertalian dengan mesin, pesawat alat kerja, bahan dan proses pengelolaannya, landasan tempat kerja dan lingkungannya, serta cara-cara melakukan pekerjaan. ${ }^{3}$

Obyek keselaamtan kerja adalah segala tempat kerja, baik di darat, di permukaan air, di dalam air dan di udara. Sedangkan pengertian kesehatan kerja adalah bagian dari ilmu kesehatan yang bertujuan agar tenaga kerja memperoleh keadaan yang sempurna, baik fisik, mental maupun sosial, sehingga memungkinkan dapat bekerja secara optimal. ${ }^{4}$

Adapun tujuan upaya keselamatan dan kesehatan kerja bertujuan untuk melindungi keselamatan tenaga kerja di kapal guna mewujudkan produktivitas kerja yang optimal, dengan cara pencegahan kecelakaan dan penyakit akibat kerja, pengendalian bahaya di tempat kerja, promosi kesehatan, pengobatan, dan rehabilitasi. ${ }^{5}$

Keselamatan dan kesehatan kerja diatur dalam Pasal 86 ayat

\footnotetext{
${ }^{3}$ Sumakmur, Keselamatan Kerja dan Pencegahan Kecelakaan, CV. Haji, Jakarta, 1987, hal. 1

${ }^{4}$ Departemen Tenaga Kerja, 1994/1995, hal. 11

${ }^{5}$ Abdul Hakim, Pertanggungjawaban Pelaku Usaha Melalui Kontrak Kerja Baku, Editor, Jakarta, 2003, hal. 65
}

(1), (2), (3) Undang-Undang Nomor 13 Tahun 2003 tentang Ketenagakerjaan, yaitu :

(1) Setiap pekerja mempunyai hak untuk memperoleh perlindungan atas :

((1)) Keselamatan dan kesehatan kerja;

((2)) Moral dan Kesusilaan;
((3)) Perlakuan yang sesuai dengan harkat dan martabat manusia serta nilai-nilai agama.

(2) Untuk melindungi keselamatan pekerja guna mewujudkan produktivitas kerja yang optimal diselenggarakan upaya keselamtan dan kesehatan kerja.

(3) Perlindungan sebagaimana yang dimaksud dalam ayat (1) dan (2) dilaksanakan sesuai dengan peraturan tertentu.

Ketentuan peraturan perundangundangan mengenai keelamatan kerja di kapal pada umumnya mengacu pada Undang-Undang Nomor 1 Tahun 1970 tentang Keselamatan Kerja dan Ordonansi Kapal 1935 (Staatblad, 1935). Pada Pasal 14 Ordonansi Kapal mengatur agar pemerintah dapat menetapkan ketentuan yang diperlukan sehubungan dengan tempat tinggal anak buah kapal, cara-cara perawatan pelaut dan ketentuan keselamatan selama tinggal dan bekerja di kapal. Jadi setiap perusahaan wajib menerapkan sistem manajemen keselamatan dan kesehatan kerja. Apalagi mengingat resiko tenaga kerja di kapal sangat berat. 


\section{3) Pengupahan}

Pengupahan merupakan sebagai salah satu aspek penting dalam perlindungan hukum tenaga kerja atau pekerja. Besarnya upah yang diperoleh anak buah kapal (ABK) didasarkan atas perjanjian kerja laut, sepanjang isinya tidak bertentangan dengan UndangUndang Nomor 13 Tahun 2003 tentang Ketenagakerjaan, Peraturan Pemerintah Nomor 7 Tahun 2000 tentang Kepelautan dan Peraturan gaji pelaut.

Upah tenaga kerja di kapal tersebut didasarkan atas :

(1) 8 jam kerja setiap hari;

(2) 44 jam per minggu;

(3) Istirahat sedikitnya 10 jam dalam jangka waktu 24 jam;

(4) Libur sehari setiap minggu;

(5) Ditambah hari-hari libur resmi (Pasal 21 ayat (1), (2) Peraturan Pemerintah Nomor 7 Tahun 2000 tentang Kepelautan).

Ketentuan di atas tidak berlaku bagi pelaut muda, artinya mereka berumur antara 16 sampai 18 tahun tidak boleh bekerja melebihi 8 jam sehari dan 40 jam seminggu serta tidak boleh dipekerjakan pada waktu istirahat, kecuali dalam pelaksanaan tugas darurat demi keselamatan berlayar. Dalam perjanjian kerja laut upah yang dimaksud tidak termasuk tunjangan atas upah lembur atau premi sebagaimana diatur dalam Pasal 402, 409, dan 415 KUH Dagang.

4) Bentuk Lain Dari Perlindungan Hukum Tenaga Kerja Dinyatakan Dalam Undang-
Undang Nomor 3 Tahun 1992 Tentang Jaminan Sosial (Jamsostek)

Pada dasarnya hak-hak anak buah kapal, baik itu nahkoda, kelasi adalah sama, walaupun ada perbedaan sedikit namun tidak begitu berarti. Hak disebutkan dalam Pasal 18 ayat (3) Peraturan Pemerintah Nomor 7 Tahun 2000 tentang Kepelautan antara lain :

(1) Hak Atas Upah

Besarnya upah yang diperoleh anak buah kapal didasarkan atas perjanjian kerja laut, sepanjang isinya tidak bertentangan dengan Undang-Undang Nomor 13 Tahun 2003 tentang Ketenagakerjaan, tidak bertentangan dengan Peraturan Pemerintah Nomor 7 Tahun 2000 tentang Kepelautan dan tidak bertentangan dengan peraturan gaji pelaut.

Berdasarkan Pasal 21

ayat (1), (2) Peraturan Pemerintah Nomor 7 Tahun 2000, upah tersebut didasarkan atas :

a. 8 jam kerja setiap hari;

b. 44 jam per minggu;

c. Istirahat sedikitnya 10 jam dalam jangka waktu 24 jam;

d. Libur sehari setiap minggu;

e. Ditambah hari-hari libur resmi.

Biasanya jumlah upah yang diterima anak buah kapal paling sedikit adalah yang sesuai dengan yang tertuang dalam perjanjian kerja laut, kecuali upah yang 
dipotong untuk hal-hal yang sudah disetujui oleh anak buah kapal tersebut atau pemotongan yang didasarkan pada hukum yang berlaku. Pengaturan mengenai pemotongan tersebut menurut Pasal 1602r Kitab UndangUndang Hukum Perdata, adalah sebagai berikut :

a. Ganti rugi yang harus dibayar;

b. Denda-denda yang harus dibayar kepada perusahaan yang harus diberi tanda terima oleh perusahaan (Pasal 1601a

KUHPerdata);

c. Iuran untuk dana (Pasal 1601s Kitab Undang-Undang Hukum Perdata);

d. Sewa rumah atau lain-lain yang dipergunakan oleh anak buah kapal di luar kepentingan dinas;

e. Uang muka (persekot) atas upah yang telah diterimanya;

f. Harga pembelian barang-barang yang dipergunakan oleh anak buah kapal diluar kepentingan dinasnya;

g. Kelebihan pembayaran upahupah yang lalu;

h. Biaya pengobatan yang harus dibayar oleh anak buah kapal (Pasal 416 Kitab Undang-
Undang Hukum Dagang);

i. Istri atau anggota keluarga lainnya sampai dengan keempat dengan jumlah maksimum 2/3 dari upah (Pasal 444-445 Kitab UndangUndang Hukum Dagang).

(2) Hak Atas Tempat Tinggal Dan Makan

Peraturan mengenai hak tempat tinggal dan makan bagi anak buah kapal diatur pada Pasal 436-438 Kitab Undang-Undang Hukum Dagang dan Pasal 13 Schepelingen Ongevalien (S.O) 1935. Berdasarkan ketentuan pasal tersebut, anak buah kapal berhak atas tempat tinggal yang baik dan layak serta berhak atas makan yang pantas yaitu cukup untuk dan dihidangkan dengan baik dan menu yang cukup bervariasi setiap hari. Ketentuan ini dipertegas dalam Peraturan Pemerintah Nomor 7 Tahun 2000 tentang Kepelautan Pasal 25, yaitu :

a. Pengusaha atau perusahaan angkutan di perairan wajib menyediakan

makanan, alat-alat pelayaran dalam jumlah yang cukup dan layak untuk setiap pelayaran bagi setiap anak buah kapal.

b. Makanan harus memenuhi jumlah, serta nilai gizi dengan jumlah 


$$
\begin{array}{lr}
\text { minimum } & 3.600 \\
\text { kalori per hari yang } & \\
\text { diperlukan anak } & \text { an kapal } \\
\text { buah agar } \\
\text { tetap sehat dalam } \\
\text { melakukan } \\
\text { tugasnya. }
\end{array}
$$

c. Air tawar harus tetap tersedia di kapal dengan cukup dan memenuhi standar kesehatan.

Apabila ketentuan di atas dilanggar, maka dapat dikatakan sebagai pelanggaran hukum, dimana anak buah kapal dapat melakukan pemaksaan terhadap perusahaan pelayaran untuk membayar ganti rugi terhadap kerugian yang diderita.

\section{(3) Hak Cuti}

Ketentuan yang mengatur hak cuti anak buah kapal terdapat dalam PasalPasal 409 dan 415 KUH Dagang, yang prinsipnya sama dengan cuti yang diberikan kepada tenaga kerja di perusahaan pada umumnya.

Pasal 409 KUH

Dagang menyebutkan :

"Bilamana nahkoda atau perwira kapal telah bekerja selama setahun berturut-turut/terusmenerus, maka mereka berhak atas cuti selama 14 hari atau bila dikehendaki pengusaha pelayaran biasa dilakukan dua kali, masing-masing delapan hari. Ini dilakukan mengingat kepentingan operasional kapal atau permintaan nahkoda".
Hak cuti ini gugur bila diajukan sebelum satu tahun masa kerjanya berakhir. Dan hak ini berlaku untuk perjanjian kerja laut yang didasarkan atas pelayaran.

Pasal 415 KUH

Dagang menyebutkan :

"Bilamana anak buah kapal telah bekerja selama setahun terusmenerus sedangkan perjanjian kerja lautnya bukan perjanjian kerja laut pelayaran, maka berhak atas cuti 7 (tujuh) hari kerja atau dua kali lima hari kerja dengan upah penuh".

(4) Hak Waktu Sakit Atau

\section{Kecelakaan}

Pengertian sakit dalam perjanjian kerja laut dilihat dari sebab-sebabnya antara lain meliputi :

\section{a. Sakit Biasa}

Seorang anak buah kapal apabila sewaktu bertugas menderita sakit maka berhak atas :

a) Pengobatan sampai sembuh, akan tetapi paling lama 52 minggu bilamana diturunkan dalam kapal, demikian juga bila dia tetap berada di kapal berhak mendapatkan

pengobatan sampai sembuh (Pasal 416 KUH Dagang).

b) Pengangkutan cumacuma ke rumah sakit atau ke kapal lain dimana ia akan dirawat dan ke tempat ditandatanganinya perjanjian kerja laut 
(Pasal $416 \quad$ KUH

Dagang).

Selama anak buah kapal sakit atau kecelakaan ia berhak atas upah sebesar $80 \%$ dengan syarat tidak lebih dari 28 minggu (Pasal 416a KUH Dagang), dan jaminan diperoleh disamping biaya perawatan sampai sembuh. Pasal tersebut mensyaratkan bahwa anak buah kapal mengadakan perjanjian kerja laut untuk waktu paling sedikit satu tahun atau bekerja terus menerus selama paling sedikit satu setengah tahun.

b. Sakit

Karena

\section{Kecelakaan}

Berdasarkan Pasal 1602 KUHPerdata, anak buah kapal yang mengalami sakit karena kecelakaan maka berhak atas :

a) Tuntutan ganti rugi bila terbukti kecelakaan tersebut disebabkan oleh kelalaian pihak perusahaan pelayaran.

b) Jika kecelakaan menimpa anak buah kapal dan mengakibatkan

meninggal, maka ganti ruginya diberikan kepada ahli warisnya.

c) Penggantian akibat kecelakaan ditambah dengan hak-hak atas perawatan.

\section{c. Kapal Tenggelam}

Pada umumnya hampir semua kapal yang beroperasi diasuransikan. Awak kapal termasuk nahkoda dijaminkan pada P \& I Club (Protection and Indernity Club). Jaminan yang diberikan kepada anak buah kapal disesuaikan dengan peraturan perundangundangan negara mengenai Anak Buah Kapal yang bersangkutan. Jadi jika kapal tenggelam tidak akan memberatkan pihak perusahaannya.

Dalam rangka pelaksanaan perlindungan hukum terhadap tenaga kerja, pemerintah telah menetapkan Undang-Undang Nomor 13 Tahun 2003 tentang Ketenagakerjaan. Salah satu tujuan ditetapkan undang-undang tersebut adalah dimaksudkan untuk menjamin hak-hak dasar pekerja dan menjamin kesamaan kesempatan serta perlakuan yang sama tanpa diskriminasi atas dasar apapun dan untuk mewujudkan kesejahteraan pekerja dan keluarganya. Begitu juga dalam Undang-Undang Nomor 21 Tahun 2004 tentang Pelayaran telah memuat tentang perlindungan hukum terhadap tenaga kerja di kapal.

Dalam pelaksanaan perlindungan hukum pasti mengalami hambatan-hambatan baik dari pihak tenaga kerja/pekerja di kapal maupun pihak perusahaan. Hambatanhambatan yang timbul dalam perlindungan hukum terhadap tenaga kerja harus diselesaikan secara damai agar kedua belah pihak, agar tidak mengganggu hubungan kerja antara tenaga kerja atau pekerja dengan perusahaan.

\section{PENUTUP}

Berdasarkan hasil penelitian dan pembahasan mengenai bentuk-bentuk perlindungan hukum terhadap tenaga kerja yang bekerja di laut dapat disimpulkan sebagai berikut :

1. Bentuk perlindungan hukum yang diatur dalam Undang-Undang 
Marsidah, Tinjauan Yuridis Tentang Bentuk-Bentuk Perlindungan Hukum Bagi Tenaga Kerja Yang Bekerja Di Laut

Halaman 374-384

Nomor 13 Tahun 2003 meliputi perlindungan hukum terhadap waktu kerja, keselamatan kerja dan kesehatan kerja, dan pengupahan.

2. Perlindungan hukum yang berdasarkan ketentuan dalam Jaminann Sosial Tenaga Kerja meliputi Hak Atas Upah, hak tempat tinggal dan rumah, hak cuti, hak waktu sakit dan kecelakaan.

DAFTAR PUSTAKA

Abdul Kadir Muhammad, 1994, Hukum Pengangkutan Darat, Laut dan Udara, PT. Citra Aditya Bhakti, Bandung.

Abdul Hakim, Pertanggungjawaban Pelaku Usaha Melalui Kontrak Kerja Baku, Editor, Jakarta, 2003.

Djoko Triyanto, Bekerja di Kapal, Cetakan Pertama, Minar Maju, Bandung, 2006.

H.M.N. Purwosutjipto, Pengertian Pokok Hukum Dagang Indonesia, Djambatan, Jakarta, 2000.

Radika Purba, Asuransi Angkutan Laut, PT. Rineka Cipta, Jakarta, 1998.

R. Subekti, Hukum Perjanjian, Alumni, Bandung, 2002.

Sumakmur, Keselamatan Kerja dan Pencegahan Kecelakaan, CV. Haji, Jakarta, 1987.

Sution Usman Adji, Djoko Prakoso, Hari Pramono, Hukum Pengangkutan Di Indonesia, Rineka Cipta, Jakarta, 1990.

Soerjono Soekanto, Pengantar Penelitian Hukum, Universitas Indonesia, Jakarta, 1981.

Undang-Undang Nomor 13 Tahun 2003 Tentang Ketenagakerjaan

Kitab Undang-Undang Hukum Perdata. Kitab Undang-Undang Hukum Dagang. Peraturan Pemerintah Nomor 1 Tahun $1998 \quad$ Tentang Pemeriksaan Kecelakaan Kapal.

\author{
Peraturan Pemerintah Nomor 07 Tahun \\ 2000 Tentang Kepelautan. \\ Departemen Tenaga Kerja, 1994/1995.
}

